\title{
Kinetics of Non-Enzymatic Synthesis of Dipeptide Cbz-Phe-Leu with AOT Reversed Micelles
}

\author{
Michiaki Matsumoto ${ }^{1, *}$ and Tadashi Hano ${ }^{2}$ \\ 1 Department of Chemical Engineering and Materials Science, Doshisha University, \\ Kyotanabe, Kyoto 610-0321, Japan \\ 2 Department of Applied Chemistry, Oita University, Oita 870-1192, Japan; thano@oita-u.ac.jp \\ * Correspondence: mmatsumol@mail.doshisha.ac.jp; Tel.: +81-774-65-6655
}

Citation: Matsumoto, M.; Hano, T. Kinetics of Non-Enzymatic Synthesis of Dipeptide Cbz-Phe-Leu with AOT Reversed Micelles. Processes 2021, 9 , 1003. https://doi.org/10.3390/ pr9061003

Academic Editor: Florian M. Wurm

Received: 10 May 2021

Accepted: 4 June 2021

Published: 5 June 2021

Publisher's Note: MDPI stays neutral with regard to jurisdictional claims in published maps and institutional affiliations.

Copyright: (c) 2021 by the authors. Licensee MDPI, Basel, Switzerland. This article is an open access article distributed under the terms and conditions of the Creative Commons Attribution (CC BY) license (https:/ / creativecommons.org/licenses/by/ $4.0 /)$.

\begin{abstract}
The non-enzymatic synthesis of N-benzyloxycarbonyl-L-phenylalanyl-L-leucine (Cbz-PheLeu) from lipophilic N-benzyloxycarbonyl-L-phenylalanine (Cbz-Phe) and hydrophilic L-leucine (Leu), by N, N'-dicyclohexylcarbodiimide (DCC) as a condensing agent, was carried out using a reversed micellar system composed of bis(2-ethylhexyl) sodium sulfosuccinate (AOT) as a surfactant and isooctane. We successfully synthesized Cbz-Phe-Leu in a short time and investigated the effects of its operational conditions, the DCC concentration, $\mathrm{w}_{0}$, and the $\mathrm{pH}$ on the kinetic parameters and the maximum yields. For dipeptide synthesis, we had to add an excess of DCC with the substrates because of the side reactions of Cbz-Phe. From the $\mathrm{pH}$ dependency of the reactivity, a partially cationic form of Leu was better for a synthesis reaction because of the enrichment of Leu at the interface by anionic AOT. The optimum water content on the dipeptide synthesis was $\mathrm{w}_{0}=28$ due to the competition of the peptide synthesis and the side reactions. The maximum yield of Cbz-Phe-Leu was 0.565 at $80 \mathrm{~h}$ under optimum experimental conditions.
\end{abstract}

Keywords: dipeptide synthesis; reversed micelle; non-enzymatic reaction; condensing agent

\section{Introduction}

Some kinds of proteins, poly and oligopeptides, and amino acids have demonstrated positive health influences and also provide numerous potential physiological functions. In contrast, L- $\alpha$-dipeptides (dipeptides) have been poorly investigated [1]. One major reason is their low availability because of a lack of cost-effective production processes. However, knowledge regarding the functions of dipeptides is gradually expanding. Dipeptides syntheses are categorized into three methods: chemical, chemoenzymatic (using an enzyme and at least one protected amino acid), and enzymatic [1]. In an enzymatic synthesis, the expression of enzymes, which catalyze the formation of the peptide bond without protecting the amino acids, are found in gene-modified microbes. However, the yields are often low, and the purification procedures are time-consuming [2]. In chemical synthesis, including solid-phase peptide synthesis, its cost is relatively high and a harmful reagent is sometimes needed, although it has the following advantages: every kind of dipeptide can be synthesized, the yield is usually high, and the procedure is simple [2]. Furthermore, they require fully protected peptides, which are difficult to dissolve into an aqueous solution due to their hydrophobicity. Peptide bond hydrolytic enzymes can also catalyze the formation of peptide bonds. Many studies have investigated the chemoenzymatic method using hydrolytic enzymes [2]. Although this method has advantages, including high stereoselectivity and mild reaction conditions, it also requires protected amino acids to form desired peptide bonds and suffers from a hydrophobicity problem [1].

Nakanishi et al. [3] reported the enzymatic synthesis of lipophilic N-benzoxycarbonyl (Cbz)-Phe-Phe-OMe from lipophilic-protected amino acids, Cbz-Phe and Phe-OMe, using thermolysin in a biphasic system. The yield in an ethyl acetate/water biphasic system exceeded that in water, although the production rate of the dipeptide in biphasic systems 
was lower than in water. Organic solvents promoted peptide synthesis with lipophilic substrates that cannot proceed in an aqueous medium because the equilibrium is mostly shifted toward the hydrolysis in an aqueous medium [4]. When one substrate is lipophilic and the other is hydrophilic, enzymatic reactions in an aqueous/organic two-phase system are conceivable.

A simple two-phase system contains bulk water, which is unfavorable for synthesis reactions. Reversed micelles have nanoscopic water droplets in bulk apolar solvents and have been used as nanoreactors in various applications $[5,6]$. They homogeneously solubilize the biomolecules in the organic phase and possess an enormous contact area $\left(10-100 \mathrm{~m}^{2} \mathrm{~cm}^{-3}\right)$. Di- and tripeptide synthesis using enzymes solubilized in reversed $\mathrm{mi}-$ celles was reported by Lüthi and Luisi [7] and Shield et al. [8]. The former work [7] studied the synthesis of lipophilic $\mathrm{N}$-benzoxycarbonyl (Cbz)-Ala-Phe-Leu- $\mathrm{NH}_{2}$ from lipophilic Cbz-Ala-Phe-OMe and hydrophilic Leu- $\mathrm{NH}_{2}$ using $\alpha$-chymotrypsin in a bis(2-ethylhexyl) sodium sulfosuccinate (AOT)/isooctane reversed micelle. Shield et al. [8] also studied the lipophilic dipeptide synthesis of Cbz-Tyr-Gly- $\mathrm{NH}_{2}$ from lipophilic Cbz-Tyr-OMe and hydrophilic Gly- $\mathrm{NH}_{2}$ using $\alpha$-chymotrypsin in a dodecyltrimethylammonium bromide /1hexanol/octane reversed micelle. However, in a reversed micellar system, as argued by Lüthi and Luisi [7], there is no easy way to recover the expensive enzymes. Though this can be achieved partly using a hollow fiber reactor or an immobilized enzyme [7,9], a simple reaction-separation system is desired. Alternatively, non-enzymatic dipeptide synthesis using reversed micelles was reported. Ranganathan et al. [10] used a condensing agent, like $\mathrm{N}, \mathrm{N}^{\prime}$-dicyclohexylcarbodiimide (DCC) and N, N'-dioctadecylcarbodiimide, to form a peptide of Cbz-AA1-AA2-OMe (AA1 = Trp, Phe, Leu, Pro, AA2 = Trp, Leu, Pro, Phe) from protected amino acids, $\mathrm{Cbz}-\mathrm{AA} 1$ and AA2-OMe, in a reversed micelle composed of AOT and isooctane. After stirring for 2 days, the yields of the dipeptides were $25-67 \%$, depending on the hydrophobicity of the amino acids. Dias et al. [11] reported a spontaneous dipeptide synthesis, AcPheIleNH ${ }_{2}$, from AcPheOEt and $\mathrm{IleNH}_{2}$ in tetradecyltrimethylammonium bromide/heptane/octanol reversed micelles. Unfortunately, it required 20 days to obtain a dipeptide yield higher than $87 \%$. These non-enzymatic methods are attractive since they avoid the problem of enzyme recovery. However, both chemical syntheses using reversed micelles required long reaction times.

In this paper, we synthesized non-enzymatically lipophilic Cbz-Phe-Leu from lipophilic protected amino acid, Cbz-Phe, and hydrophilic free amino acid, Leu, or protected amino acid, Leu- $\mathrm{NH}_{2}$ using a reversed micellar system composed of DCC, AOT, and isooctane in a short time by replacing Leu-OMe with Leu and Leu- $\mathrm{NH}_{2}$ and its kinetic behaviors were investigated. We examined the effect of the operational conditions, the molar ratio, $w_{0}$, of water solubilized within the reversed micelles to the amount of the surfactant present, the $\mathrm{pH}$ of the water core, and the DCC concentration in the dipeptide synthesis on the kinetic parameters and the maximum yields. Figure 1 shows the schematic representation of the Cbz-Phe-Leu synthesis within reversed micelles.

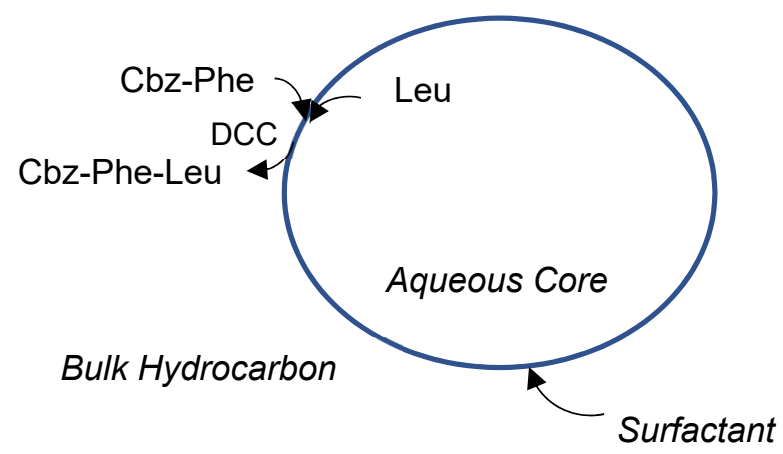

Figure 1. Schematic representation of dipeptide synthesis using a reversed micelle. 


\section{Materials and Methods}

\subsection{Chemicals}

Bis(2-ethylhexyl) sodium sulfosuccinate (AOT), isooctane and N, N'-dicyclohexylcarbodiimide (DCC), N-benzoxycarbonyl-L-phenylalanine (Cbz-Phe), L-leucine (Leu) and L-leucineamide (Leu- $\mathrm{NH}_{2}$ ) were purchased from Wako Pure Chemical Industries, Ltd., and N-benzoxycarbonyl-L-phenylalanyl-L-leucine (Cbz-Phe-Leu) was purchased from Sigma Chem. Co. These products were used as received. All the remaining reagents were of analytical grade and used without further purification.

\subsection{Dipeptide Synthesis in Reversed Micelles}

The synthesis of Cbz-Phe-Leu using DCC in a reversed micellar solution was carried out in a stirred tank thermostated at $298 \mathrm{~K}$. The micellar solution was prepared by mixing $10 \mathrm{~cm}^{3}$ of aqueous leucine solution $\left(1 \mathrm{~mol} / \mathrm{m}^{3}\right)$ and $150 \mathrm{~cm}^{3}$ of isooctane solution containing AOT $\left(100 \mathrm{~mol} / \mathrm{m}^{3}\right)$ and $\mathrm{Cbz}-\mathrm{Phe}\left(1 \mathrm{~mol} / \mathrm{m}^{3}\right)$. The $\mathrm{pH}$ of the aqueous solution was adjusted by a phosphate buffer. After $40 \mathrm{~cm}^{3}$ of isooctane solution containing DCC was added to the reactor and stirred at $2 \mathrm{~s}^{-1}$, the reaction started. Our preliminary experiment confirmed that the order of adding the substrate and DCC barely affected the reaction rate. Samples were withdrawn at proper time intervals. Concentrations are based on the whole reaction volume.

\subsection{Analysis}

Standard Cbz-Phe and Cbz-Phe-Leu solutions were used for preparing the calibration curves. The concentrations of Cbz-Phe and Cbz-Phe-Leu were determined by HPLC (Shimadzu LC-10ADvp) with an ODS column (Simpack CLC-ODS, Shimadzu, Kyoto, Japan) and a mixture of $2 \mathrm{~g} / \mathrm{L}$ triethylamine solution (45\%) of $\mathrm{pH} 2.3$ that was adjusted by phosphoric acid and acetonitrile (55\%). Protected peptides and amino acids were detected with a UV detector at $260 \mathrm{~nm}$ (Shimadzu SPD10AV).

\section{Results and Discussion}

Figure 2 shows the time courses of the $\mathrm{Cbz}-\mathrm{Phe}, \mathrm{Cbz}-\mathrm{Phe}-\mathrm{Leu}$ concentrations and the yield from the Cbz-Phe to the Cbz-Phe-Leu $\left(\mathrm{w}_{0}=28, \mathrm{pH}\right.$ 5, initial concentrations Cbz-Phe and Leu $=1 \mathrm{~mol} / \mathrm{m}^{3}$ ). Immediately after the reaction started, Cbz-Phe-Leu was observed. Conversely, when we used Leu- $\mathrm{NH}_{2}$ as a substrate, no new product peaks were found within such a quick reaction time. As described previously [10], it may take longer to form Cbz-Phe-Leu- $\mathrm{NH}_{2}$ because cationic Leu- $\mathrm{NH}_{2}$ in an aqueous core electrostatically interacts with the anionic surfactant AOT at the interface. Although the net charge of Leu (pI = 5.98) in a water core of $\mathrm{pH} 5$ was partially positive, the electrostatic interaction of Leu may not be as strong as that of Leu- $\mathrm{NH}_{2}$. We successfully prepared dipeptide using a non-enzymatic reversed micellar system in a short time.

Figure 2 also shows a decrease in the $\mathrm{Cbz}-\mathrm{Phe}$ concentration and an increase in the Cbz-Phe-Leu concentration in time, and after $3 \mathrm{~h}$, both concentrations reached a steady state, suggesting that the dipeptide formation was a reversible reaction. However, the decrease in the $\mathrm{Cbz}$-Phe concentration did not correspond to the increase in the $\mathrm{Cbz}$ Phe-Leu concentration. Selectivity $S$, which is defined by the ratio of the Cbz-Phe-Leu produced to the Cbz-Phe reacted, is also shown in Figure 2. During the experiment, the selectivity was almost constant, 0.46 , suggesting that the consumption of Cbz-Phe by the side reactions occurred at a constant ratio. To confirm this, the reaction behavior without Leu in an aqueous core was investigated, and the concentration changes of Cbz-Phe in the presence and absence of Leu are shown in Figure 3. Despite the absence of Leu, the concentration of $\mathrm{Cbz}$-Phe decreased with time. The difference in both lines approximately corresponds to the production of Cbz-Phe-Leu. Scheme 1 shows the reaction scheme of dipeptide synthesis using DCC in an anhydrous homogeneous medium [12]. Although it is expected that the main by-product will be $N$-acylurea, identification of by-products in a reversed micellar system is a subject for future analysis. 


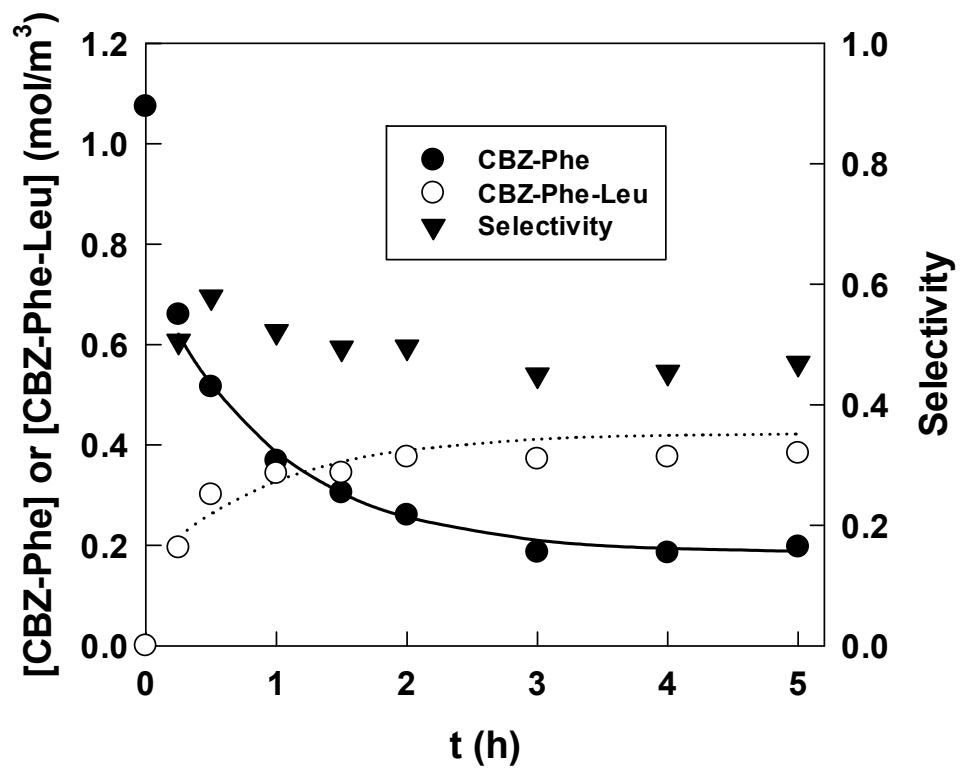

Figure 2. Time courses of Cbz-Phe and Cbz-Phe-Leu concentrations, and selectivity $\left(w_{0}=28, \mathrm{pH} 5\right.$, $\mathrm{DCC}=7 \mathrm{~mol} / \mathrm{m}^{3}$ ). Solid and dotted lines were calculated from the rate constants and selectivity.

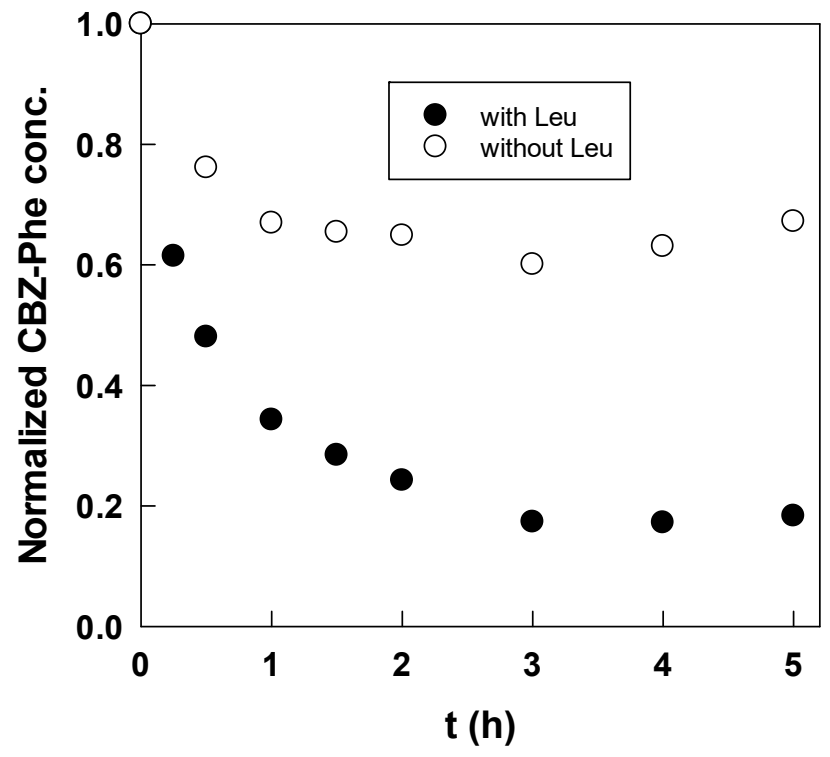

Figure 3. Time courses of Cbz-Phe concentrations in presence and absence of Leu in aqueous core $\left(w_{0}=28, \mathrm{pH} 5, \mathrm{DCC}=7 \mathrm{~mol} / \mathrm{m}^{3}\right)$.

This dipeptide formation is apparently expressed as Equation (1) based on the results shown in Figure 2:

$$
\text { Cbz-Phe }+ \text { Leu } \rightleftharpoons \text { Cbz-Phe-Leu }+\mathrm{H}_{2} \mathrm{O}
$$

We conducted an experiment with Cbz-Phe and Leu $=1 \mathrm{~mol} / \mathrm{m}^{3}$, whose concentrations are based on the whole reaction volume. Because Leu dissolved in the water core and Cbz-Phe dissolved in an isooctane solution, the Leu concentration in the water core was enriched by 20 times. Therefore, an excessive amount of Leu exists at the interface between the water core and the bulk isooctane solution compared to Cbz-Phe. The reaction rate of Equation (1), r, was simplified to the following reversible first-order reaction:

$$
r=k \cdot S \cdot[\mathrm{Cbz} \cdot \mathrm{Phe}]-k^{\prime}[\mathrm{Cbz} \cdot \mathrm{Phe} \cdot \mathrm{Leu}]
$$


where $k$ and $k^{\prime}$ are the apparent forward and reverse reaction rate constants and $S$ is the ratio of Cbz-Phe-Leu produced to the Cbz-Phe reacted.

Equation (3) was derived by integrating Equation (2) in a batch reactor;

$$
-\ln \frac{[\mathrm{Cbz} \cdot \mathrm{Phe}]-[\mathrm{Cbz} \cdot \mathrm{Phe}]_{e}}{[\mathrm{Cbz} \cdot \mathrm{Phe}]_{0}-[\mathrm{Cbz} \cdot \mathrm{Phe}]_{e}}=\left(k \cdot S+k^{\prime}\right) t
$$

where subscripts 0 and e denote the initial and equilibrium states, respectively.

Figure 4 shows the relation with Equation (3), and the plot was almost linear, suggesting that the approximation to Equation (2) was valid.

At equilibrium state $(r=0)$, the following equation was derived.

$$
\frac{[\mathrm{Cbz} \cdot \mathrm{Phe} \cdot \mathrm{Leu}]_{e}}{[\mathrm{Cbz} \cdot \mathrm{Phe}]_{e}}=\frac{k \cdot S}{k^{\prime}}=K
$$

where $K$ is an apparent equilibrium constant of Equation (1).

From Equations (3) and (4), the rate constants were obtained, and the solid and dotted lines in Figure 2 were calculated using the obtained rate constants and selectivity.

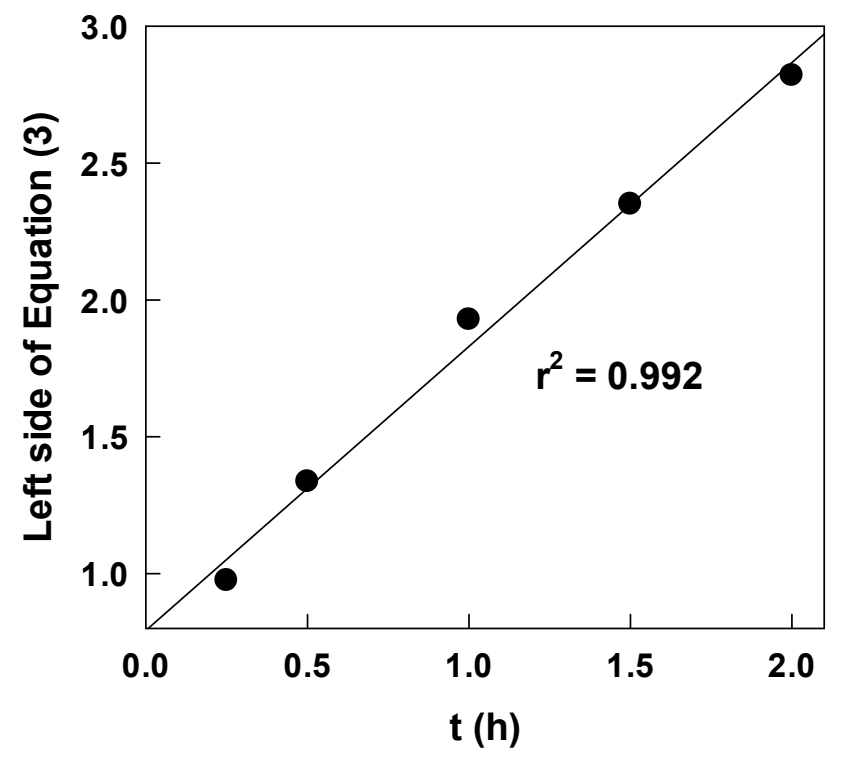

Figure 4. Plots based on Equation (3) to determine rate constants.

\subsection{Effect of DCC Concentration}

DCC as a condensing agent in an anhydrous homogeneous medium reacts with the carboxylic acid to form $O$-acylurea (1). This intermediate yields a dipeptide via direct coupling with the amine and, formation of carboxylic acid anhydride, which subsequently yields the amide by reaction with the amine, as shown in Scheme 1. Table 1 lists the effects of DCC concentration. An excess in DCC compared with the substrate concentrations was needed. In addition to the formation of by-products such as $N$-acylurea, the following other factors are considered. Ranganathan et al. [10] stated that DCC played the role of co-surfactant, therefore, a part of DCC is located at the micellar interface and may be partly hydrated by water not from Cbz-Phe but from the aqueous bulk. The other point is that the formed Cbz-Phe anhydride is hydrolyzed at the micellar interface. The reactions of the Cbz-Phe anhydride with Leu or water are competitive at the interface. These two factors, in addition to the formation of by-products, may cause excess DCC.

\subsection{Effect of $w_{0}$}

Reversed micelles are characterized by parameter $w_{0}$, which is the number of water molecules per surfactant molecule: $w_{0}=\mathrm{H}_{2} \mathrm{O} / \mathrm{AOT}$. An increase in $\mathrm{w}_{0}$ leads not to more 
reversed micelles but to a larger average diameter for them [13]. Table 2 lists the effect of $\mathrm{w}_{0}$ on the reaction rate constants, selectivity, equilibrium constants, and maximum yields. The value of $\mathrm{w}_{0}$ was varied by changing the water concentration while maintaining an AOT concentration constant at a $100 \mathrm{~mol} / \mathrm{m}^{3}$. Yield at $w_{0}=28$ was maximum and, at the lowest $\mathrm{w}_{0}$, the peptide was not synthesized at all. For a reversed micelle of low $\mathrm{w}_{0}$, because most water molecules are involved in the hydration of the head groups of surfactants, the whole aqueous microenvironment is rigid and the micro-viscosity of the micellar water was higher than in the bulk solutions. Therefore, the reactivity in the lowest $\mathrm{w}_{0}$ may be poor. Thermodynamic equilibrium constants, $K$, and the conversion rate constant of Cbz-Phe, $k$, increased with the $w_{0}$ values. However, an increase in $k$ values does not increase the yield, suggesting that an increase in $w_{0}$ caused an acceleration in the side reactions involving $\mathrm{Cbz}$-Phe. For the results of the competition of peptide synthesis and the side reactions, the yield was maximum at $w_{0}=28$.

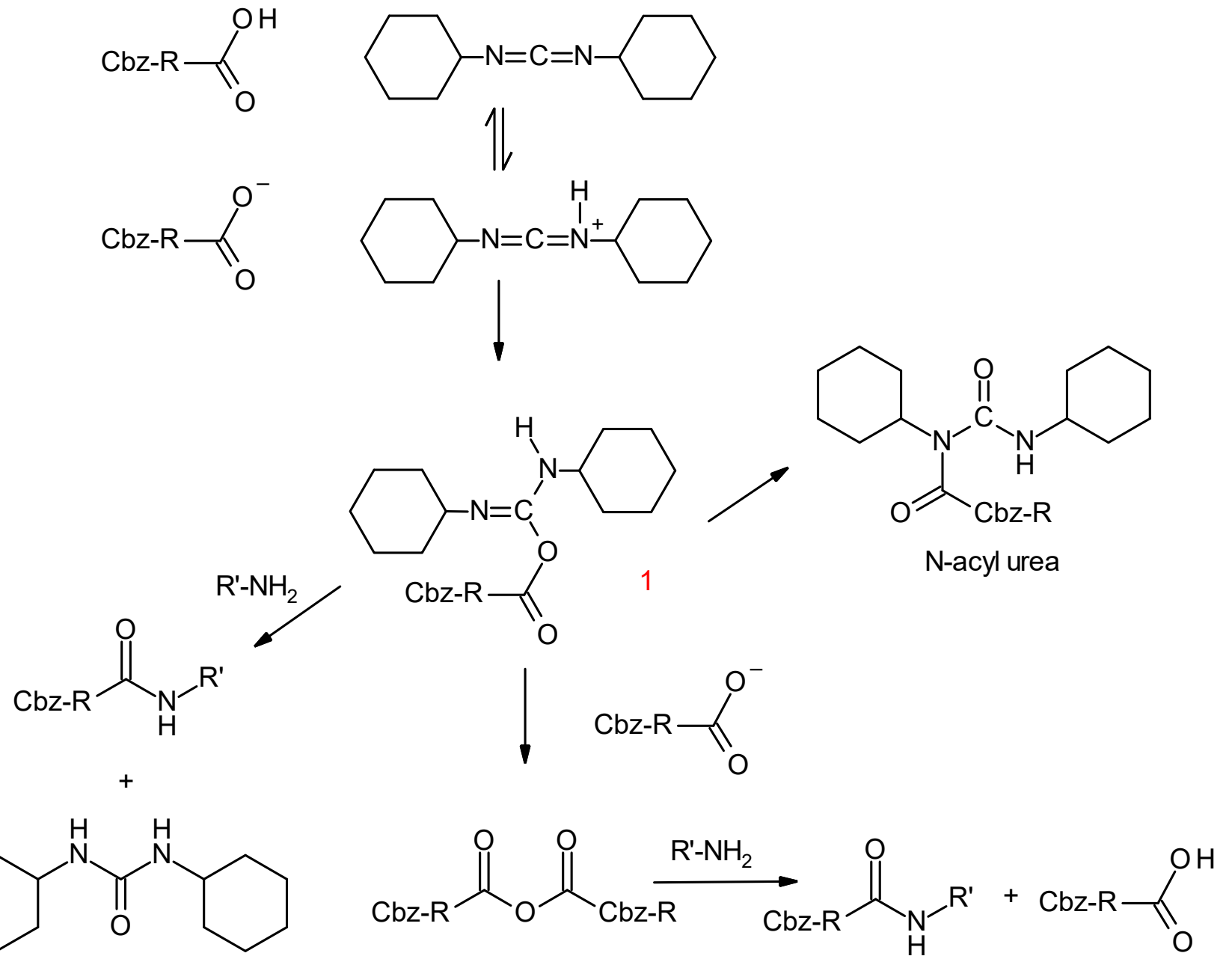

Scheme 1. Reaction scheme of dipeptide synthesis using a condensing agent DCC. 
Table 1. Effect of DCC concentration on dipeptide synthesis $\left(w_{0}=28, \mathrm{pH}=5\right)$.

\begin{tabular}{|c|c|c|c|c|c|}
\hline $\operatorname{DCC}\left(\mathrm{mol} / \mathrm{m}^{3}\right)$ & $k\left[\mathrm{~h}^{-1}\right]$ & $k^{\prime}\left[h^{-1}\right]$ & $S$ & $K$ & Yield $_{\text {max }}$ \\
\hline 1 & & ND & & & ND \\
\hline 3 & $1.15 \pm 0.43$ & $1.16 \pm 0.43$ & $0.38 \pm 0.00$ & $0.38 \pm 0.00$ & 0.214 \\
\hline 5 & $1.67 \pm 0.70$ & $0.56 \pm 0.24$ & $0.36 \pm 0.00$ & $1.09 \pm 0.04$ & 0.247 \\
\hline 7 & $1.50 \pm 0.24$ & $0.34 \pm 0.05$ & $0.46 \pm 0.01$ & $2.03 \pm 0.00$ & 0.357 \\
\hline 10 * & - & - & $0.33 \pm 0.01$ & - & 0.330 \\
\hline
\end{tabular}

* Rate and equilibrium constants could not be determined because the Cbz-Phe concentrations were monotonically decreasing with time. The values are at $5 \mathrm{~h}$. ND: Cbz-Phe-Leu was not detected.

Table 2. Effect of $w_{0}$ on dipeptide synthesis $\left(\mathrm{pH}=5, \mathrm{DCC}=7 \mathrm{~mol} / \mathrm{m}^{3}\right)$.

\begin{tabular}{cccccc}
\hline $\boldsymbol{w}_{\mathbf{0}}$ & $\boldsymbol{k}\left[\mathbf{h}^{-\mathbf{1}}\right]$ & $\boldsymbol{k}^{\prime}\left[\mathbf{h}^{-\mathbf{1}}\right]$ & $\boldsymbol{S}$ & $\boldsymbol{K}$ & Yield $_{\max }$ \\
\hline 5.6 & \multicolumn{5}{c}{$\mathrm{ND}$} \\
14 & $1.48 \pm 0.62$ & $0.28 \pm 0.27$ & $0.31 \pm 0.02$ & $1.61 \pm 0.16$ & ND \\
28 & $1.50 \pm 0.24$ & $0.34 \pm 0.05$ & $0.46 \pm 0.01$ & $2.03 \pm 0.00$ & 0.357 \\
56 & $2.37 \pm 1.68$ & $0.33 \pm 0.27$ & $0.34 \pm 0.01$ & $2.41 \pm 0.12$ & 0.320 \\
\hline
\end{tabular}

ND: Cbz-Phe-Leu was not detected.

\subsection{Effect of $p H$}

Because the hydrophilic substrate, Leu, is amphoteric, aqueous $\mathrm{pH}$ is expected to affect the charge state of Leu, that is, its reactivity. Table 3 lists the effects of $\mathrm{pH}$. The maximum yield was obtained around $\mathrm{pH} 5$. Here the $\mathrm{pH}$ values are those of the aqueous buffers with which the micellar solution was prepared. Anionic surfactant, AOT, was reported to be somewhat lower than the $\mathrm{pH}$ of the water within reversed micelles [14]. At the optimum $\mathrm{pH}$, we expected that Leu, with a $\mathrm{pI}$ of 5.98 and $\mathrm{pKa}_{1}=2.36$, could exist as a cationic form to some extent at the micellar interface. As described previously, no fully cationic Leu- $\mathrm{NH}_{2}$ was reacted at all with Cbz-Phe because the cationic Leu- $\mathrm{NH}_{2}$ was bound to the anionic AOT by a strong electrostatic interaction. On the contrary, a partially cationic Leu was enriched in the vicinity of the micellar interface with the aid of the electrostatic interaction. Therefore, for the results of the competition of the enrichment effect and the electrostatic interaction, the yield was maximum around $\mathrm{pH} 5$.

Although dipeptide Cbz-Phe-Leu was observed in a short time $(\sim 5 \mathrm{~h})$, the reaction was carried out for $80 \mathrm{~h}$. A yield of 0.565 was obtained under the optimum condition $\left(w_{0}=28, \mathrm{pH} 5, \mathrm{DCC}=7 \mathrm{~mol} / \mathrm{m}^{3}\right)$.

Table 3. Effect of $\mathrm{pH}$ on dipeptide synthesis $\left(w_{0}=28, \mathrm{DCC}=7 \mathrm{~mol} / \mathrm{m}^{3}\right)$.

\begin{tabular}{cccccc}
\hline $\mathbf{p H}$ & $\boldsymbol{k}\left[\mathbf{h}^{-\mathbf{1}}\right]$ & $\boldsymbol{k}^{\prime}\left[\mathbf{h}^{-\mathbf{1}}\right]$ & $\boldsymbol{S}$ & $\boldsymbol{K}$ & Yield $_{\max }$ \\
\hline 1.02 & & $\mathrm{ND}$ & $\mathrm{ND}$ \\
3.18 & $1.73 \pm 0.06$ & $0.76 \pm 0.03$ & $0.41 \pm 0.00$ & $0.93 \pm 0.00$ & 0.291 \\
4.16 & $1.68 \pm 0.28$ & $0.63 \pm 0.20$ & $0.43 \pm 0.01$ & $1.14 \pm 0.12$ & 0.329 \\
5.05 & $1.50 \pm 0.24$ & $0.34 \pm 0.05$ & $0.46 \pm 0.01$ & $2.03 \pm 0.00$ & 0.357 \\
6.02 & $1.82 \pm 0.11$ & $0.59 \pm 0.06$ & $0.27 \pm 0.00$ & $0.84 \pm 0.02$ & 0.203 \\
7.02 & $0.53 \pm 0.43$ & $0.26 \pm 0.23$ & $0.26 \pm 0.00$ & $0.52 \pm 0.01$ & 0.173 \\
8.88 & \multicolumn{7}{c}{$\mathrm{ND}$} & & $\mathrm{ND}$ \\
\hline
\end{tabular}

ND: Cbz-Phe-Leu was not detected.

Author Contributions: Conceptualization, M.M. and T.H.; methodology, M.M.; formal analysis, M.M.; investigation, M.M.; data curation, M.M..; writing-original draft preparation, M.M.; writingreview and editing, T.H.; All authors have read and agreed to the published version of the manuscript.

Funding: This research received no external funding.

Institutional Review Board Statement: Not applicable.

Informed Consent Statement: Not applicable.

Data Availability Statement: Not applicable. 
Acknowledgments: We thank Fumio Katagiri for his experimental assistance.

Conflicts of Interest: The authors declare no conflict of interest.

\section{References}

1. Yagasaki, M.; Hashimoto, S. Synthesis and application of dipeptides; current status and perspectives. Appl. Microbiol. Biotechnol. 2008, 81, 13-22. [CrossRef] [PubMed]

2. Yazawa, K.; Numata, K. Recent advances in chemoenzymatic peptide synthesis. Molecules 2014, 19, 13755-13774. [CrossRef] [PubMed]

3. Nakanishi, K.; Matsuno, R. Kinetics of enzymatic synthesis of peptides in aqueous/organic biphasic systems: Thermolysincatalyzed synthesis of N-(benzyloxycarbonyl)-L-phenylalanyl-L-phenylalanine methyl ester. Eur. J. Biochem. 1986, 161, 533-540. [CrossRef] [PubMed]

4. Nagashima, T.; Watanabe, A.; Kise, H. Peptide synthesis by proteases in organic solvents: Medium effect on substrate specificity. Enzym. Microb. Technol. 1992, 14, 842-847. [CrossRef]

5. Tonova, K.; Lazarova, Z. Reversed micelle solvents as tools of enzyme purification and enzyme-catalyzed conversion. Biotechnol. Adv. 2008, 26, 516-532. [CrossRef]

6. Mohd-Setapar, S.H.; Mohamad-Aziz, S.N.; Chuong, C.S.; Yunus, M.A.C.; Zaini, M.A.A.; Kamaruddin, M.J. A review of mixed reversed micelle system for antibiotic recovery. Chem. Eng. Commun. 2014, 201, 1664-1685. [CrossRef]

7. Lüthi, P.; Luisi, P.L. Enzymatic synthesis of hydrocarbon-soluble peptides with reversed micelles. J. Am. Chem. Soc. 1984, 106, 7285-7286. [CrossRef]

8. Shield, J.W.; Ferguson, H.D.; Cleason, K.K.; Hatton, T.A. Enzymatic reactions in reversed micelles at low solubilized water concentrations. ACS Symp. Ser. 1989, 392, 90-103.

9. Fadnavis, N.W.; Luisi, P.L. Immobilized enzyme in reversed micelles: Studies with gel-trapped trypsin and $\alpha$-chymotrypsin in AOT reversed micelles. Biotechnol. Bioeng. 1989, 33, 1277-1282. [CrossRef] [PubMed]

10. Ranganathan, D.; Singh, G.P.; Ranganathan, S. Peptide bond formation at the micellar interface. J. Am. Chem. Soc. 1989, 111, 1144-1145. [CrossRef]

11. Dias, A.I.; Feliciano, A.S.; Cabral, J.M.S.; Prazeres, D.M.F. Chemical synthesis and crystallization of the dipeptide $\mathrm{AcPheIleNH}_{2}$ in TTAB/heptane/octanol reversed micelles. J. Colloid Interface Sci. 2007, 305, 198-201. [CrossRef] [PubMed]

12. Valeur, E.; Bradley, M. Amide bond formation: Beyond the myth of coupling reagents. Chem. Soc. Rev. 2009, 38, 606-631. [CrossRef] [PubMed]

13. Eskici, G.; Axelsen, P.H. The size of AOT reverse micelle. J. Phys. Chem. B 2016, 120, 11337-11347. [CrossRef] [PubMed]

14. Shield, J.W.; Ferguson, H.D.; Bommarius, A.S.; Hatton, T.A. Enzymes in reversed micelles as catalysts for organic phase synthesis reaction. Ind. Eng. Chem. Fundam. 1986, 25, 603-612. [CrossRef] 